\title{
HERD-LEVEL RISK FACTORS ANALYSIS FOR BOVINE BRUCELLOSIS IN JAMMU, JAMMU AND KASHMIR
}

\author{
M. SINGH ${ }^{1 *}$, M. A. MALIK ${ }^{1}$, A. KHAJURIA² AND J. GUPTA ${ }^{2}$
}

\begin{abstract}
${ }^{1}$ Division of Veterinary Public Health and Epidemiology, Faculty of Veterinary Science and Animal Husbandry, Sher-e-Kashmir University of Agricultural Sciences and Technology of Jammu, R. S. Pura, Jammu-181 102, Jammu and Kashmir, India

${ }^{2}$ Animal Husbandry Department, Jammu, Jammu and Kashmir, India
\end{abstract}

\begin{abstract}
Bovine brucellosis is endemic in India and inter-herd transmission of disease may involve multiple factors. In this context, a study was conducted to assess the herd-level risk factors involved in transmission of bovine brucellosis in Jammu, Jammu and Kashmir, India. Pooled milk samples from bovine herds and information on 6 risk factors (sample area, bovine species on farm, history of abortion/retention of placenta on farm, purchase of animals, type of breeding on farm and size of herd) were collected from six villages of Jammu region. Milk samples $(\mathrm{n}=175)$ were tested by milk ring test (MRT) to detect brucellosis positive herds. MRT results in association with risk factors were analysed by univariable and multivariable logistic regression analysis. Regression analysis identified sample area, species reared on farm, history of abortion/retention of placenta on farm and herd size as the significant factors associated with herd seropositivity in the study area.
\end{abstract}

Key words: Bovine brucellosis, Herd prevalence, Risk factors

\section{INTRODUCTION}

Bovine brucellosis is endemic in India (Boral et al., 2009). The disease is responsible for huge economic losses in country due to abortions, reduced fertility and loss in milk production (Singh et al., 2015). Recently the Government of India has initiated National Animal Disease Control Programme (NADCP) to eradicate foot and mouth disease(FMD) and brucellosis in country which aims to eradicate brucellosis by 2025 from the country.

The transmission of brucellosis from one herd to another herd may involve multiple factors. Some of the factors for herd prevalence of bovine brucellosis have been identified and include factors associated with animals such as artificial insemination, purchase of animals, herd size, management system, and history of abortion. In different areas, different factors predominate and it becomes necessary to identify such predominant factors to formulate control strategies in a region (Makita et al., 2011; Chand and Chhabra, 2013; Assenga et al., 2016).

Jammu district of Jammu and Kashmir, India, shares international border with Pakistan. To fulfil their food demands, the people of border region are greatly involved in animal husbandry

\footnotetext{
*Corresponding Author
} 
and some of the areas have high bovine population density. Further, the animal rearers of the region frequently buy and sell their animals in local areas as well as the neighbouring states viz., Punjab and Haryana where brucellosis has been reported by many workers (Kaur et al., 2006; Chand and Chhabra, 2013). The animal breeding involves both natural mating and artificial insemination. The risk factors for herd-level prevalence of brucellosis in the region have not been identified. The present study was an attempt to identify the potential risk factors associated with herd prevalence of bovine brucellosis in Jammu district of Jammu and Kashmir.

The study was targeted in six areas viz., Agra Chak, Baspur Bangla, Badyal Brahmana, Bega, Sai Khurd and Purana Pind, and pooled herd milk samples were collected from bovine herds. Samples were collected from 175 herds and analysed. The herds have 1 to 65 animal(s) in milk production. The herds were divided into 3 categories based upon their size in the study (Table 1). None of the herds was vaccinated with Brucella abortus S19 vaccine. The sampling was done from November 2017 to March 2018.

The samples were tested by milk ring test (MRT) as per the protocol of OIE (2018). Samples were stored at $4^{\circ} \mathrm{C}$ for $24 \mathrm{hr}$ prior to MRT. For
MRT, samples and antigen were brought to room temperature. In a small test tube, $30 \mu \mathrm{L}$ of antigen was added to $1 \mathrm{~mL}$ milk sample and incubated at $37^{\circ} \mathrm{C}$ for $1 \mathrm{hr}$. The formation of coloured (pink) ring at top was positive for brucellosis. The antigen for MRT was procured from Division of Biological Products, Indian Veterinary Research Institute, Bareilly, Uttar Pradesh (India).

The herd owners in the study area were questioned using a structured questionnaire on various management conditions. Before that, a questionnaire was framed based on the studies published on risk factor analysis of bovine brucellosis (Makita et al., 2011; Sanogo et al., 2012; Boukary et al., 2013; Chand and Chhabra, 2013; Assenga et al., 2016) and pre-tested on a group of animal keepers to identify the risk factors to be considered for study area. Many of the risk factors reported elsewhere such as presence of calving pen in the farm, intensiveness of management, education of respondents and knowledge of brucellosis were removed in pretesting phase. The 6 risk factors included in selected questionnaire were viz., village, bovine species in farm, history of abortion/retention of placenta in farm, purchase of animals, type of breeding on farm and size of herd.

The MRT results and questionnaire responses were compiled and analysed using SPSS 16.0

Table 1. Attributes of bovine herds $(n=175)$ sampled in the study

\begin{tabular}{lllllllll}
\hline Sample area & \multicolumn{3}{c}{ Herd size (productive animals) } & \multicolumn{3}{c}{ Species on farm } & Total & \multirow{2}{*}{$\begin{array}{c}\text { Percent } \\
\text { of total }\end{array}$} \\
\cline { 2 - 6 } & $\mathbf{1 - 5}$ & $\mathbf{6 - 1 0}$ & $\mathbf{> 1 0}$ & Cattle & Buffalo & Both & & \\
\hline Badyal Brahmna & 27 & 9 & 1 & 9 & 7 & 21 & 37 & 21.1 \\
Agra Chak & 21 & 11 & 4 & 15 & 13 & 8 & 36 & 20.6 \\
Baspur Bangla & 43 & 4 & 3 & 18 & 10 & 88 & 50 & 28.6 \\
Purana Pind & 8 & 0 & 0 & 1 & 0 & 7 & 8 & 4.6 \\
Bega & 20 & 7 & 1 & 9 & 6 & 13 & 28 & 16.0 \\
Sai Khurd & 16 & 0 & 0 & 11 & 1 & 4 & 16 & 9.1 \\
\hline Total & $\mathbf{1 3 5}$ & $\mathbf{3 1}$ & $\mathbf{9}$ & $\mathbf{6 3}$ & $\mathbf{3 7}$ & $\mathbf{7 5}$ & $\mathbf{1 7 5}$ & \\
\hline
\end{tabular}


(SPSS Inc., Chicago). Apart from descriptive statistics, the risk factors were analysed by univariable analysis and the factors having $\mathrm{p}<0.25$ were further subjected to multivariable logistic regression with stepwise backward likelihood ratio method. The model fitness was gauged by change in log likelihood method as well as Hosmer and Lemeshow test.

The study was an attempt to identify risk factors in Jammu region of Jammu and Kashmir having large bovine population and is first of its kind for the study area. The study used MRT for identification of brucellosis positive herds as the test has been considered suitable in identifying infected herds (OIE, 2018) and is used in implementation of national bovine brucellosis control programme in India (Shome et al., 2015). The relative cheapness and quick results than other diagnostic tests are the other added benefits.

The highest prevalence of herd brucellosis was reported in Bega $(25.57 \%)$ followed by Sai Khurd $(25.00 \%)$ while none of the samples of Purana Pind was positive $(\mathrm{p}=0.07)$ (Table 2). It seems brucellosis is endemic in Bega and Sai Khurd localities as purchase of animals was not a significant factor for herd seropositivity in the study (as discussed below). In Purana Pind the absence of disease could be due to low number of samples available for screening. The herds

Table 2. Univariable analysis of risk factors associated with bovine brucellosis at herd level*

\begin{tabular}{|c|c|c|c|c|c|c|}
\hline Factor & Classes with in factor & $\begin{array}{l}\text { Number } \\
\text { of samples }\end{array}$ & $\begin{array}{l}\text { Samples } \\
\text { positive }(\%)\end{array}$ & $\begin{array}{l}\text { P- } \\
\text { value }\end{array}$ & $\begin{array}{l}\text { Odds } \\
\text { ratio }\end{array}$ & $\begin{array}{l}P \text { - } \\
\text { value }\end{array}$ \\
\hline $\begin{array}{l}\text { Sample } \\
\text { area }\end{array}$ & $\begin{array}{l}\text { Badyal Brahmna } \\
\text { Agra Chak } \\
\text { Baspur Bangla } \\
\text { Purana Pind } \\
\text { Bega } \\
\text { Sai Khurd }\end{array}$ & $\begin{array}{l}37 \\
36 \\
50 \\
8 \\
28 \\
16\end{array}$ & $\begin{array}{l}3(8.11 \%) \\
3(8.33 \%) \\
6(12.00 \%) \\
0 \\
8(28.57 \%) \\
4(25.00 \%)\end{array}$ & 0.070 & $\begin{array}{l}0.27 \\
0.27 \\
0.41 \\
0.00 \\
1.20 \\
1.00\end{array}$ & $\begin{array}{l}0.111 \\
0.120 \\
0.216 \\
0.999 \\
0.798\end{array}$ \\
\hline $\begin{array}{l}\text { Farm } \\
\text { species }\end{array}$ & $\begin{array}{l}\text { Cattle } \\
\text { Buffalo } \\
\text { Mixed farm }\end{array}$ & $\begin{array}{l}63 \\
37 \\
75\end{array}$ & $\begin{array}{l}14(22.22 \%) \\
2(5.40 \%) \\
8(10.67 \%)\end{array}$ & 0.037 & $\begin{array}{l}2.39 \\
0.48 \\
1.00\end{array}$ & $\begin{array}{l}0.070 \\
0.367\end{array}$ \\
\hline $\begin{array}{l}\text { History } \\
\text { on farm }\end{array}$ & $\begin{array}{l}\text { No history } \\
\text { Abortion in } 2^{\text {nd }} \text { half of } \\
\text { pregnancy } \\
\text { Retention of placenta } \\
\text { Both abortion and } \\
\text { retention of placenta }\end{array}$ & $\begin{array}{l}104 \\
5 \\
17 \\
49\end{array}$ & $\begin{array}{l}14(13.46 \%) \\
2(40.00 \%) \\
0 \\
8(17.39 \%)\end{array}$ & 0.116 & $\begin{array}{l}1.00 \\
4.29 \\
0.00 \\
1.25\end{array}$ & $\begin{array}{l}0.128 \\
0.998 \\
0.638\end{array}$ \\
\hline $\begin{array}{l}\text { Purchase } \\
\text { of animals }\end{array}$ & $\begin{array}{l}\text { Yes } \\
\text { No }\end{array}$ & $\begin{array}{l}105 \\
70\end{array}$ & $\begin{array}{l}13(12.38 \%) \\
11(15.71 \%)\end{array}$ & 0.530 & 0.76 & 0.531 \\
\hline $\begin{array}{l}\text { Type of } \\
\text { breeding } \\
\text { on farm }\end{array}$ & $\begin{array}{l}\text { Natural mating } \\
\text { Artificial insemination } \\
\text { Both }\end{array}$ & $\begin{array}{l}42 \\
76 \\
57\end{array}$ & $\begin{array}{l}4(9.52 \%) \\
14(18.42 \%) \\
6(10.53 \%)\end{array}$ & 0.281 & $\begin{array}{l}0.89 \\
1.92\end{array}$ & $\begin{array}{l}0.870 \\
0.213\end{array}$ \\
\hline Herd size & $\begin{array}{l}1-5 \text { animals } \\
6-10 \text { animals } \\
>10 \text { animals }\end{array}$ & $\begin{array}{l}135 \\
31 \\
9\end{array}$ & $\begin{array}{l}20(14.81 \%) \\
1(3.22 \%) \\
3(33.33 \%)\end{array}$ & 0.051 & $\begin{array}{l}0.35 \\
0.07\end{array}$ & $\begin{array}{l}0.158 \\
0.029\end{array}$ \\
\hline
\end{tabular}

*The six risk-factors were analysed by univariable logistic regression. The samples positive (\%) and odds ratio were analyzed for statistical significance by chi-square test 
Table 3. Multivariable logistic regression analysis of risk factors associated with bovine brucellosis at herd level*

\begin{tabular}{llccc}
\hline Factor & Classes with in factor & Samples positive \% & Odds ratio & P-value \\
\hline Sample area & Badyal Brahmna & 8.11 & 0.39 & 0.316 \\
& Agra Chak & 8.33 & 0.48 & 0.407 \\
& Baspur Bangla & 12 & 0.41 & 0.268 \\
& Purana Pind & 0 & 0.00 & 0.999 \\
& Bega & 28.57 & 3.21 & 0.146 \\
& Sai Khurd & 25 & 1.00 & \\
\hline Farm species & Cattle & 22.22 & 1.72 & 0.344 \\
& Buffalo & 5.4 & 0.14 & 0.093 \\
& Mixed farm & 10.67 & 1.00 & \\
\hline History & No history & 13.46 & 1.00 & \\
on farm & Abortion in 2 ${ }^{\text {nd }}$ half of pregnancy & 40 & 6.58 & 0.125 \\
& Retention of placenta & 0 & 0.00 & 0.998 \\
& Both abortion and retention & 17.39 & 2.28 & 0.157 \\
& of placenta & & & \\
\hline Herd size & $1-5$ animals & 14.81 & 0.13 & 0.067 \\
& 6-10 animals & 3.22 & 0.02 & 0.013 \\
& $>10$ animals & 33.33 & 1.00 & \\
\hline
\end{tabular}

*The four risk-factors were analysed by multivariable logistic regression. The odds ratio were analyzed for statistical significance by chi-square test

rearing cattle alone $(22.22 \%)$ had higher prevalence than herds rearing buffalo alone $(5.40 \%)(\mathrm{p}=0.037)$ and could be due to lower susceptibility of buffaloes to Brucella abortus infection (Adesiyun et al., 2010). Similar results were reported by Chand and Chhabra (2013) for Punjab and Haryana states.

Herds having history of abortion in $2^{\text {nd }}$ half of pregnancy exhibited higher prevalence $(40 \%)$ while herds with no history of abortion were also positive $(13.46 \%)$. This could be due to presence of carrier animals in the farm. Herds having history of purchase of animals had lower prevalence than those having no such history $(\mathrm{p}=0.53)$. Further, herds practising artificial insemination had higher positive prevalence $(p=0.281)$. The reason for higher prevalence in herds practising artificial insemination is unexplainable as the frozen semen used for artificial insemination comes from semen collection centres certified as brucellosis-free by veterinary services. It was observed that natural mating was mainly employed in buffaloes in the region and as the brucellosis prevalence in buffaloes was lesser in the study, the prevalence estimates for natural mating were also lower. The herds with size $>10$ animals had highest positivity $(33.33 \%)$ followed by $1-5$ animals $(14.81 \%)(\mathrm{p}=0.051)$. High positivity in large herds had been reported by many workers (Makita et al., 2011; Sanogo et al., 2012; Boukary et al., 2013), but study also reported higher seropositivity in small herds indicating the endemicity nature of disease especially in Bega and Sai Khurd.

In univariate analysis, 2 out of 6 factors i.e. purchase of animals and breeding method had p-value higher than 0.25 and were removed for multivariable logistic regression analysis (Table 2 ). The remaining 4 factors (sample area, species on farm, and history of abortion/ retention of placenta on farm and herd size) 
were tested in multivariable regression analysis and were retained in the final model (Table 3). The odds ratios associated with each variable are depicted in Table 2 and Table 3. Thus, the study identified four factors viz., sample area species on farm, history of abortion/retention of placenta on farm and herd size to be significant factors associated with herd-level brucellosis in the region. To the authors' knowledge, this is the first report on herd-level

\section{REFERENCES}

Adesiyun AA, Fosgate GT, Persad A, Campbell M, Seebaransingh $\mathrm{R}$ et al., 2010. Comparative study on responses of cattle and water buffalo (Bubalus bubalis) to experimental inoculation of Brucella abortus biovar 1 by the intraconjunctival route- A preliminary report. Trop Anim Health Prod, 42: 1685-1694, doi: $10.1007 / \mathrm{s} 11250-010-9621-3$

Assenga JA, Matemba LE, Malakalinga JJ, Muller SK and Kazwala RR, 2016. Quantitative analysis of risk factors associated with brucellosis in livestock in the Katavi-Rukwa ecosystem, Tanzania. Trop Anim Health Prod, 48: 303-309, doi: $10.1007 / \mathrm{s} 11250-015-0951-\mathrm{z}$

Boral R, Singh M and Singh DK, 2009. Status and strategies for control of brucellosis- A review. Indian J Anim Sci, 79(12): 1191-1199

Boukary AR, Saegerman C, Abatih E, Fretin D, Bada RA et al., 2013. Seroprevalence and potential risk factors for Brucella Spp. infection in traditional cattle, sheep and goats reared in urban, periurban and rural areas of Niger. PLoS One, 8: 1-12, doi: 10.1371/journal.pone. 0083175

Chand P and Chhabra R, 2013. Herd and individual animal prevalence of bovine brucellosis with associated risk factors on dairy farms in Haryana and Punjab in India. Trop Anim Health Prod, 45: 1313-1319, doi: 10.1007/s11250-013$0362-y$ risk factors analysis for bovine brucellosis in the region.

Conflict of interest: The authors declare no conflict of interest.

\section{ACKNOWLEDGMENTS}

The authors are thankful to the Dean, Faculty of Veterinary Sciences and Animal Husbandry, R. S. Pura to provide financial support for this study.

Kaur P, Sharma NS, Jand SK and Oberoi MS, 2006. Isolation and identification of Brucella abortus from aborted cattle and buffaloes and evaluation of their antibiogram. Indian J Anim Sci, 76(2): 105-108

Makita K, Fevre EM, Waiswa C, Eisler MC, Thrusfield M et al., 2011. Herd prevalence of bovine brucellosis and analysis of risk factors in cattle in urban and peri-urban areas of the Kampala economic zone, Uganda. BMC Vet Res, 7: 60, doi: $10.1186 / 1746-6148-7-60$

OIE (World Organization for Animal Health), 2018. Chapter 2.1.4. Brucellosis (Brcuella abortus, B. melitensis and B. suis)

Sanogo M, Abatih E, Thys E, Fretin D, Berkvens D et al., 2012. Risk factors associated with brucellosis seropositivity among cattle in the Central Savannah-forest area of Ivory Coast. Prev Vet Med, 107: 51-56, doi: 10.1016/ j.prevetmed.2012.05.010

Shome R, Nagalingam M, Shome BR, Misri J, Padmashree BS et al., 2015. Milk ring test from lab to field: A surveillance strategy for states under brucellosis control program. Indian J Anim Sci, 85(10): 1077-1080

Singh BB, Dhand NK and Gill JPS, 2015. Economic losses occurring due to brucellosis in Indian livestock populations. Prev Vet Med, 119: 211215, doi: 10.1016/j.prevetmed.2015.03.013

Received 10.07.2020, Accepted - 15.09.2020, Published - 01.12.2020 